\title{
Cardiovascular effects of antimuscarinic agents and beta3-adrenergic receptor agonist for the treatment of overactive bladder
}

\author{
Gian Marco Rosa, Danilo Baccino, Alberto Valbusa, Carolina Scala, Fabio \\ Barra, Claudio Brunelli \& Simone Ferrero
}

To cite this article: Gian Marco Rosa, Danilo Baccino, Alberto Valbusa, Carolina Scala, Fabio Barra, Claudio Brunelli \& Simone Ferrero (2018): Cardiovascular effects of antimuscarinic agents and beta3-adrenergic receptor agonist for the treatment of overactive bladder, Expert Opinion on Drug Safety, DOI: 10.1080/14740338.2018.1453496

To link to this article: https://doi.org/10.1080/14740338.2018.1453496

Accepted author version posted online: 15

Mar 2018.

Submit your article to this journal

Q View related articles $₫$

View Crossmark data 
Publisher: Taylor \& Francis

Journal: Expert Opinion on Drug Safety

DOI: $10.1080 / 14740338.2018 .1453496$

Cardiovascular effects of antimuscarinic agents and beta3-adrenergic receptor agonist for the treatment of overactive bladder

Gian Marco Rosa ${ }^{1}$, Danilo Baccino ${ }^{1}$, Alberto Valbusa ${ }^{1}$, Claudio Brunelli ${ }^{1}$, Carolina Scala ${ }^{2,3}$, Fabio Barra $^{2,3}$, Simone Ferrero ${ }^{2,3, *}$

\footnotetext{
Affiliations

${ }^{1}$ Department of Internal Medicine, Cardiology, Ospedale Policlinico San Martino, Largo R. Benzi 10, 16132 Genoa, Italy

${ }^{2}$ Academic Unit of Obstetrics and Gynecology, Ospedale Policlinico San Martino, Largo R. Benzi 10, 16132 Genoa, Italy

${ }^{3}$ Department of Neurosciences, Rehabilitation, Ophthalmology, Genetics, Maternal and Child Health (DiNOGMI), University of Genoa, Italy
}

\section{*Corresponding Author}

Telephone 01139010 511525; Fax 01139010511525 ; E-mail: simone.ferrero@unige.it 


\begin{abstract}
Introduction: Overactive bladder (OAB) syndrome is common in the general population, particularly in elderly patients. Antimuscarinic drugs (AMs) are considered the mainstay pharmaceutical treatment of $\mathrm{OAB}$ whereas $\beta 3$-adrenoceptor agonists, such as mirabegron, represent a good alternative. Owing to the important role of muscarinic and $\beta 3$ receptors in cardiovascular $(\mathrm{CV})$ tissue and to the fact that OAB patients often have CV comorbidities, the safety-profile of these drugs constitute an important challenge.

Area covered: The aim of this review is to evaluate the CV effects of AMs and mirabegron in OAB. A systematic literature search from inception until December 2017 was performed on PubMed and Medline.

Expert opinion: AMs are generally considered to have good CV safety profile but, however, they may cause undesirable adverse events, such as dry mouth, constipation. CV AEs are rare but noteworthy, the most common $\mathrm{CV}$ consequences related to the use of these drugs are constituted by an increase in HR and QT interval. Mirabegron has similar efficacy and tolerability to AMs but causes less adverse events, with either modest hypertension and modest increase in $\mathrm{HR}(<5 \mathrm{bpm})$ being the most commonly reported.
\end{abstract}

Keywords: antimuscarinics, cardiovascular adverse effects, heart rate, heart rate variability, hypertension, Mirabegron, QT prolongation 


\section{Article highlights:}

- Overactive bladder (OAB) is a syndrome characterized by urinary urgency, with or without urgent urinary incontinence (UUI), and is usually associated with increased daytime frequency and nocturia. OAB often involves elderly people, who often present various cardiovascular (CV) comorbidities.

- Antimuscarinics (AMs) represent the most commonly used drugs in the context of OAB. Eight different drugs are currently marketed for pharmacological management of OAB: darifenacin hydrobromide, fesoterodine fumarate, imidafenacin, oxybutynin chloride, propiverine hydrochloride, solifenacin succinate, tolterodine tartrate and trospium chloride.

- The most common CV adverse effects associated with the use of AMs are represented by increase in heart rate (HR) and QT interval prolongation. Only three cases of serious QT prolongation and polymorphic ventricular tachycardia (TdP) were reported with the use of solifenacin.

- Mirabegron, a selective $\beta-3$ adrenoceptor agonist represents a good alternative for the treatment of OAB. Mirabegron presented similar efficacy and tolerability to AMs in phase II and III trials, but with reduced side effects characterized by modest hypertension and an increase in $\mathrm{HR}<5$ bpm.

- The potential impact of AMs and mirabegron on cardiac function should be taken in consideration by physician especially in older patients who are likely to present $\mathrm{CV}$ risk factor and other comorbidities.

- Despite the safe pharmacological profile of AM drugs and mirabegron, a clinical and ECG monitoring might be useful especially in selected patients such as those aged $>80$ years or with CV comorbidities. 


\section{Introduction}

Overactive bladder $(\mathrm{OAB})$ syndrome is characterized by urinary urgency, with or without urgency urinary incontinence (UUI), and is usually associated with increased daytime frequency and nocturia [1]. OAB is a common condition worldwide: in Europe, Canada, the United States and Japan, epidemiologic studies have reported a prevalence of $8.0 \%$ to $16.5 \%$ in adults, with rates similar in men and women $[2,3]$. It should be borne in mind that $\mathrm{OAB}$ is a heterogeneous condition with a multifactorial underlying pathophysiology.

Various measures may be used to generally improve this condition and to prevent worsening. These may include bladder training, pelvic floor muscle exercises, and lifestyle modifications [4]. Pharmacological therapy is second-line treatment. Antimuscarinics (AMs) are still the main drugs used. However, they have a conspicuously low compliance rate, as they often cause adverse effects (AEs) such as dry mouth, constipation and blurred vision [5,6]. Mirabegron, the only $\beta 3$-adrenoceptor agonist approved for clinical use, has an efficacy comparable to that of AMs, but has a better safety profile, often similar to that of placebo [7]. In fact, as OAB often involves elderly people, who may have various cardiovascular (CV) comorbidities [8], a good safety profile is necessary. Anyway, both muscarinic and $\beta$-adrenergic receptors are present in both the $\mathrm{CV}$ and urinary systems [9]. Consequently, drugs that interact with these receptors have to necessarily exert $\mathrm{CV}$ effects. The issue of the CV safety of these drugs has therefore aroused great interest. The aim of this systematic review is to analyze the CV AEs of drugs administered for the treatment of OAB.

\section{The role of muscarinic and $\beta$ receptors on the regulation of cardiac function}

\subsection{Muscarinic receptors}

The heart presents various subtypes of muscarinic receptors: M1, M2, M3 [10]. Among them, the activation of $\mathrm{M} 2$ receptors plays the most important role.

In the human heart, M2 receptors can be found not only in the sino-atrial (SA) and atrio-ventricular (AV) nodes, but also in other sites such as the endocardium, epicardium, and T-tubules of atrial and ventricular cardiomyocytes [11]. M2-mediated stimulation results in the inhibition of the intrinsic rate 
of firing of pacemaker cells; therefore, heart rate (HR) decreases and AV conduction reduces. Furthermore, M2 modulation may also reduce atrial and ventricular contractility $[11,12]$.

Conversely, the role of M1 and M3 receptors is still not fully understood. M1 receptors are localized in the SA node. Indeed, the activation of M1 receptors in both humans and animals can increase HR, and this could explain why low doses of AMs may induce paradoxical tachycardia [11]. M3 receptors are widely expressed; they can be found in the SA node, the AV node and the ventricles. Their activation may influence both the pace-making activity of the SA and AV nodes and the regulation of cardiac muscle contractile activity by shortening action potential duration [13,14]. Abramochkin et al. [15] have demonstrated, in the murine heart, that M3 stimulation of the SA node reduces pacemaker activity, consequently, causing HR decrease. Anyway, these effects are very modest when compared with M2response but may play a role in pathological condition such as heart failure, ischemia or atrial fibrillation owing to an increased number of this receptor subtype and to a decrease in M2 receptors; thus, the role of these receptors is therefore not insignificant [16]. In these conditions, M1 and M3 receptors may increase automaticity and contractility through a phospholipase c (PLC) dependent mechanism that enhances activity of L-type calcium Channel (LTcc) [17]. Furthermore, Lamping et al. have shown that M3 receptors may dilate coronary arteries in mice; however, in humans, this effect is unclear [18].

\section{$2.2 \beta$-adrenoceptors}

Conversely, distribution and function of $\beta 3$-adrenoceptors remain controversial. Anyway, $\beta 3-$ adrenoceptors have been identified in various tissues in both humans and other species [19, 20].

In human bladder, $\beta 3$-adrenoceptors constitute $97 \%$ of total $\beta$-adrenoceptor messenger RNA (21). They may therefore be considered the main subtype receptor that mediates relaxation of detrusor smooth muscle during the storage phase.

On the other hand, all three adrenoceptor subtypes $(\beta 1, \beta 2, \beta 3)$ are expressed in the CV system, given rise to potential concerns about the $\mathrm{CV}$ effects of $\beta$-adrenoceptors agonists. For what regards $\beta$ receptors, the general consensus is that $\beta 1$ and $\beta 2$ adrenoceptors coexist in the human heart, with the $\beta 1$-adrenoceptor predominating with a ratio of approximately 70:30 in the atria and 80:20 in the ventricles [22]. HR, contractile force and transmission velocity through the AV node are increased by $\beta 1$ - mediated effects [23]. 
$\beta 2$ receptors have similar effects. They play an important role in pathologic conditions such as congestive heart failure, when $\beta 1$ receptors density and function are markedly reduced. By contrast, $\beta 2$ receptor function remains unaffected [23].

The $\beta 3$ receptor is functionally different from $\beta 1$ and $\beta 2$ receptors, and its stimulation could activate different intracellular pathways depending on the cellular context and on the grade of tissue receptor expression [24]. In ventricular myocytes $\beta 3$ receptors expression is low and its activation is linked to an inhibitory intracellular pathway [25]. By contrast, in atrial tissue, in which $\beta 3$ receptors are more expressed, their stimulation is linked to an activating pathway and so increases contractility [25]. However, in ventricular myocytes, the grater expression of $\beta 1$ and $\beta 2$ receptors minimizes the negative inotropic effect of $\beta 3$ receptors. The impact of $\beta 3$ receptor on HR is still unclear; receptor stimulation at the level of the SA node may activate two different pathways: one mediated by adenylate cyclase, which increases automaticity, and another mediated by nitric oxide synthase/guanylate cyclase, which exerts an opposite action [26]. Sterin Borda et al. [27] suggest that $\beta 3$ receptor stimulation leads primarily to a positive chronotropic effect while guanylate cyclase pathway is activated later and exerts a negative feedback on the adenylate cyclase pathway. Thus, at present, the few available reports on the physiological role of $\beta 3$ receptors are sometimes discordant. This has made clinical development of a $\beta 3$-agonist such as mirabegron a challenge.

\section{Cardiac effects of OAB drugs}

\subsection{Cardiac effects of antimuscarinic drugs}

The main CV effects of AMs are increased HR, hence tachycardia and palpitations, and decreased HR variability (HRV) (Table 1). Therefore, if AMs are prescribed it is advisable to monitor HR and HRV especially in older patients and in presence of CV comorbidities [28].

AMs may induce increase HR because of the M2 cardiac receptor block caused by these drugs. The effect on HR is marked in case of those drugs that do not have high M3 selectivity, implying that they significantly inhibit M2 receptors, too (Figure 1). According to several studies, tachycardia is an independent CV risk factor and can trigger ventricular arrhythmias [29]. Moreover, reduced HRV (which represents the heart response to the activity of the autonomic nervous system and may be considered an indicator of hypervagal tone) may increase the risk of myocardial infarction, dangerous arrhythmias, cardiac mortality and death from other causes in general population [30]. 
It has been found that elevated resting HR is a prognostic negative factor not only after myocardial infarction but also in patients with heart failure and is closely associated with all cause- mortality in general population and particularly in hypertensive subjects $[31,32]$. Various mechanisms may be involved, including heightened arterial wall stress, increased blood pressure, impaired arterial compliance and the increased instability of atherosclerotic plaques [33]. Moreover, tachycardia may both raise cardiac oxygen demand and at the same time, lower the cardiac oxygen supply by shortening the diastolic phase. In a healthy heart this might be of little relevance, while in elderly patients or those with CV comorbidities, it could be a risk factor.

Furthermore, prolongation of the QT interval, induction of polymorphic ventricular tachycardia (TdP) and sudden cardiac death may occur in patients treated with AMs. However, QT prolongation and its consequences cannot be attributed to the direct activity of AMs but may be an indirect effect due to the inhibition of the rapid component of the delayed rectifier potassium current (Ikr), thereby blocking the human Ether-a-go-go-Related Gene (hERG) potassium channel in the heart [34]. This term is used to indicate the protein or channel derived from the homonymous gene, which determines an increase in the time of repolarization and thus in the QT interval. A drug with antagonist activity on hERG channel may prolong QT interval by modifying the activity of ion channels on the surface of cardiac myocytes, consequently inducing an intracellular Ca $2+$ overload, thereby giving rise to fluctuations in the electric membrane potential [35]. These variations can, in a dose-dependent manner, cause early afterdepolarizations (EADs), which constitute a major trigger of re-entrant ventricular arrhythmias, such as Torsade de pointe (TdP) [35]. This arrhythmia is self-limiting but, in some cases, might degenerate into ventricular fibrillation.

Furthermore, in the clinical scenario, these drugs, even at low doses, might interact with other factors that can cause QT prolongation, such as hydro-electrolytic disorders (hypokalemia, hypomagnesemia), genetic predisposition or diseases. An interesting finding is that women are at higher risk of developing drug-induced QT prolongation and drug-induced arrhythmias than men [36,37]. While major differences may be found between men and women [38], the underlying mechanisms responsible for this predisposition of women are not completely understood.

\subsection{Adverse cardiovascular effects of mirabegron}

Mirabegron is a potent agonist of the human $\beta 3$ adrenoceptor. However, in vitro and in vivo studies have also shown effects on $\beta 1$ adrenoceptors $[39,40]$. 
Oral administration of mirabegron has been seen to increase HR in dogs and humans $[41,42]$. This effect is dose-dependent, and much more evident at supra-therapeutic doses [43].

Mirabegron is able to increase HR to a far higher degree in dogs than in men, according to Korstanje et al. [44]. This effect is partly mediated by cross-activation of the $\beta 1$-adrenoceptor, as mirabegron has a greater affinity toward canine $\beta 1$-receptor [45]. Likewise, mirabegron could increase systolic blood pressure by increasing $\beta 1$ inotropic effects. However, in one study on dogs, mirabegron was associated with a decrease in SBP; this could be partially due to the presence of $\beta 3$ receptors in the vascular system in dogs, which could explain a vasodilatory effect. Alternatively, it could be the result of $\beta 3$ negative inotropic effects. However, this mechanism is not clear and further studies are needed [46].

On the other hand, Mo et al. [39] demonstrated that mirabegron increases the force of atrial contraction by activating $\beta 1$-adrenoceptors, but not $\beta 3$-adrenoceptors. The effect was indirect, possibly owing to the release of adrenaline. Additionally, a separate nonspecific depressant effect on the contractile function of the atrium has also been demonstrated in the presence of a $\beta 1$-adrenoceptor antagonist (which was not mediated by $\beta 2$ or $\beta 3$-adrenoceptors) [44]. The reason for this effect remains to be completely clarified.

Although pharmacological mechanisms of mirabegron on inducing CV effects are not fully understood, an experiment study conducted by Van Gelderen et al [47] in human healthy volunteers has shown interesting results. In this study, the administration of a supratherapeutic dose (200 $\mathrm{mg}$ ) of mirabegron in combination with the $\beta 1$ selective antagonist bisoprolol or the $\beta 1 / \beta 2$ antagonist propanolol showed in both cases a reduction in mirabegron positive chronotropic and hypertensive effects suggesting that these are at least partly mediated by $\beta 1$ receptor stimulation. Moreover, results of this studies do not support the hypothesis that pure $\beta 3$ receptor stimulation has a negative inotropic effect.

Similarly to AMs, mirabegron may act on the QT by blocking the hERG channel. However, no cases of TdP have been reported and, according to an interesting review from our group, the finding of QT prolongation $>500 \mathrm{msec}$ is a very rare event [42]. In dogs, at exposures 6.5-fold higher than the maximal registered human dose (MRHD), the QT interval (when adequately corrected for HR increase using Fridericia correction method, QtcF) has not displayed prolongation [44]. In analyses conducted on isolated perfused canine ventricular tissue, mirabegron has neither shown effects on potassium channels, sodium channels, or calcium channels, nor caused any delay in cell repolarization at doses ranging from 4.5- to 24.5-fold higher than the $\mathrm{C}_{\max }$ observed at the MRHD [48].

\section{Clinical studies}




\subsection{Clinical studies on AMs}

The AM drugs currently available for $\mathrm{OAB}$ treatment are darifenacin hydrobromide, fesoterodine fumarate, imidafenacin, oxybutinin chloride, propiverine hydrochloride, solifenacin succinate, tolterodine tartrate, and trospium chloride [49].

\subsubsection{Heart rate and HRV}

In the literature, the AMs that exert the greatest effects on HR are tolterodine, fesoterodine, propiverine and trospium [28].

Tolderodine is not selective for a muscarinic receptor subtype and may therefore cause cardiac effects by stimulating M2-subtype receptors [50].

In a prospective 7-day exposure, 3-way crossover randomized placebo-controlled trial conducted by Olshansky et al. [51] involving healthy subjects over 50 years old, tolterodine (4 mg), darifenacin (15 mg) and placebo were evaluated with regard to changes in HR. This study showed that, although marked changes in HR $(>10 \mathrm{bpm})$ were similar across the three groups, the treatment with tolterodine was associated with a significantly higher mean 24-hour HR and a significantly higher minimum HR compared with darifenacin. Furthermore, in the same study, tolterodine was associated with a significant reduction in HRV, which is an important predictor of cardiac and all-cause mortality.

The issue of increased HR was also investigated in a post-marketing prospective randomized controlled open-label study conducted by Hsiao et al. [52] in 21 women, in which tolterodine was significantly associated with an increase in HR after 4, 8 and 12 weeks. This finding was confirmed in a placebocontrolled study on 30 women, in which tolterodine at doses of $4 \mathrm{mg}$ and $8 \mathrm{mg}$ were associated with HR increase compared with placebo. Moreover, tolterodine $(8 \mathrm{mg})$ also reduced HRV in comparison with placebo [53]

Fesoterodine is another AM that has been correlated with an increase in HR. In a randomized doubleblind multi-center placebo-controlled trial conducted on 836 patients, treatment with fesoterodine was correlated with a mean increase in HR of $3.3 \mathrm{bpm}$ and $3.9 \mathrm{bpm}$ at doses of $4 \mathrm{mg}$ and $8 \mathrm{mg}$, respectively, in comparison with placebo $(0.8 \mathrm{bpm})$ [54]. Similar results emerged in another double-blind trial, in which the mean change in HR was $1 \mathrm{bpm}$ for placebo, $3 \mathrm{bpm}$ for fesoterodine at $4 \mathrm{mg}$, and $4 \mathrm{bpm}$ for fesoterodine at $8 \mathrm{mg}[55]$.

Regarding propiverine, in a randomized double-blind, placebo-controlled, crossover study, two doses (20 mg q.d and $15 \mathrm{mg}$ t.i.d) of this drug were compared with placebo and oxibutynin. It emerged that 
both regimens had clear effects on HRV and mean HR, while oxibutynin had a similar effect to that of placebo [56].

In the American prescribing information, trospium (20 mg) immediate release (IR) is related to an increase of $9 \mathrm{bpm}$ in $\mathrm{HR}$, while the extended release (ER) formulation has been associated with an increase of $3 \mathrm{bpm} \mathrm{[57].} \mathrm{In} \mathrm{an} \mathrm{interesting} \mathrm{review,} \mathrm{Guay} \mathrm{et} \mathrm{al.} \mathrm{[58]} \mathrm{observed} \mathrm{that} \mathrm{trospium} \mathrm{(100} \mathrm{mg)} \mathrm{was}$ able to increase HR by $18 \mathrm{bpm}$.

On opposite, darifenacin, imidafenacin, oxybutynin and solefinacin have not shown any clinically significant effect on HR [59-62]

\subsubsection{QT prolongation and TdP}

Four AMs have shown hERG inhibition in in vitro studies: solifenacin, tolterodine, oxibutinin and propiverine $[63,64]$. However, clinically significant episodes were only seen with solifenacin. In September 2016, solifenacin was re-categorized as having a possible risk of TdP, which means that the drug is associated with QT interval prolongation, albeit in rare cases. However, there is no evidence of this effect when it is taken as recommended [65].

In the MILAI study, a multi-center open-label phase-IV study, $2.4 \%$ of patients who had taken solifenacin at $2.5 \mathrm{mg}$ or $5 \mathrm{mg}$ had a QTcF interval over $450 \mathrm{~ms}$ at the end of treatment, and $1.4 \%$ displayed a 30 - $60 \mathrm{~ms}$ increase in QTcF duration from the baseline [66]. The Symphony Study found a slight increase in mean QTcF following 12 weeks of solifenacin at $2.5 \mathrm{mg}, 5 \mathrm{mg}$ or $10 \mathrm{mg} /$ day [67].

Three cases of QT prolongation and TdP in patients using solifenacin have been reported in the literature. The first case involved an 81-year-old woman in whom the QT interval was normal prior to the prescription of solifenacin (QT $400 \mathrm{~ms}$; QTc $360 \mathrm{~ms}$ ); after two weeks of therapy with solifenacin ( $5 \mathrm{mg} /$ day), she suffered a syncopal episode. An ECG recorded immediately after the event revealed marked QT prolongation (QT $600 \mathrm{~ms}$; QTc $580 \mathrm{msec}$ ). After nine days, new episodes of TdP and syncope occurred, prompting interruption of solifenacin treatment; after withdrawal of the drug, ECG revealed a markedly shortened QT (QT $500 \mathrm{msec}$; QTc 408) [68].

The second case, described in 2012, concerned an 81-year-old woman who developed recurrent episodes of syncope and TdP requiring resuscitation. At the time, she was on therapy with solifenacin $(10 \mathrm{mg} /$ day) and antiarrhythmic cibenzoline to control atrial fibrillation. ECG showed a prolonged repolarization time (QT $680 \mathrm{~ms}$; QTc 660). Following the withdrawal of solifenacin, the QTc interval decreased to $458 \mathrm{~ms}$. In this case, however, a synergistic action of cibenzoline and solifenacin may have played a role in prolonging QT [69]. 
The third case occurred in 2015 and concerned an 84-year-old male who had taken solifenacin (10 $\mathrm{mg} /$ day) for 15 days. It was taken to hospital owing to episodes of syncope and sustained ventricular tachycardia. Following resuscitation, ECG revealed QT prolongation (QTc $548 \mathrm{~ms}$ ); three days after solifenacin withdrawal, the QT interval was $420 \mathrm{~ms}$ and TdP did not recur [70].

There is no published evidence that solifenacin blocks the hERG channel. However, this drug enhances the late calcium transient current and causes EADs in human induced stem cell-derived cardiomyocytes [71].

Another AM drug that was related with different reports of TdP is terodiline. This drug is an hERG channel inhibitor that was associated with QTc prolongation in a concentration dependent manner. Due to this fact and to different reports of cardiac dysrhythmia including advanced atrio-ventricular block, TdP and ventricular fibrillation, it was withdrawn in 1991 [72,73]. The withdrawal of this drug might be also due to the finding of an increased dispersion of the ventricular repolarization duration, which has an important pro-arrhythmic role [72].

In vitro studies have shown that tolterodine is a blocker of hERG and that prolongs the action potential duration (APD) [63]. However, despite its widespread clinical use, no significant correlation with QT prolongation and TdP has been found either in clinical trials or in post-marketing surveillance [52, 74,75]. Furthermore, these effects have not been demonstrated in poor metabolizers, in whom drug concentrations are higher. IKr channel affinity of tolterodine is similar to that of dofetilide [63], which is included in the "QT drug list" and is clearly correlated with QT prolongation and TdP.

The fact that a potent block of the hERG channel in vitro did not translate into clinically significant QT prolongation could be explained by the contemporary block of LTcc, which partly counteracts the QTprolonging effect of IKr block [63]

With regard to other AMs, in vitro and in vivo findings are concordant: for what concerns propiverine, in vitro and in vivo studies on guinea pig [64] and human heart tissue [76] have demonstrated that this drug not only blocks the hERG channel but also slowly activates IKr, LTcc and inward rectifying $\mathrm{K}$ current (IK1), resulting in APD reduction. In a double-blind randomized placebo-controlled study on healthy women, propiverine did not show statistically significant QT prolongation [76]. Oxybutynin, another hERG blocker, acts like propiverine by blocking IK1 and LTcc, and tends to reduce rather than prolong APD. Indeed, in a study conducted on elderly subjects with incontinence found no association with QT prolongation [77].

\subsection{Clinical studies on mirabegron}


The CV safety-profile of mirabegron, the only clinically available $\beta 3$-adrenoceptor agonist, appears to be good and comparable to that of AMs. This drug has been approved for the treatment of OAB in Europe, the USA, Canada and Japan [78].

Anyway, it may present unwanted CV AEs, such as increased blood pressure, HR, pulse rate (PR) and QT prolongation. A recent drug-use results survey assessing the safety of mirabegron in approximately 10,000 patients confirmed statistically significant benefits in quality of life and symptom questionnaire scores. Physicians judged this drug to be "effective" in $80.7 \%$ of patients, while $63.6 \%$ of patients achieved a minimal 3-point clinically important change from the baseline in the mean Overactive Bladder Symptom Score [79].

In an interesting prospective study regarding the efficacy and tolerability of mirabegron on an unselected patient population in daily clinical practice, Balachandran et al. [80] found that mirabegron brought significant benefits in quality of life and symptom questionnaires. The study showed that mirabegron may be more effective in patients who have less severe symptoms prior to treatment. It has low AEs and is well-tolerated. However, although the benefits are not striking, the rate of discontinuation owing to AEs is low. Furthermore, a real-world, post marketing, prospective, observational study showed that treatment with mirabegron was judged "effective" in $83.3 \%$ of patients and "ineffective" in $16.7 \%$ of patients [81].

This was the first prospective clinical study involving patients with current or previous CV disorders, while in the registration studies assessing the efficacy and safety of mirabegron, patients with major CV pathologies, prolonged QT interval or those taking drugs that could cause prolonged QT had not been enrolled.

\subsubsection{Heart rate effects and tachycardia events}

This review shows that the use of mirabegron is associated with a modest increase in PR and HR (Table 2).

In a phase-II dose-ranging study (DRAGON) of mirabegron, only a slight, but statistically significant, increase in PR versus placebo emerged at supra-therapeutic doses of $100 \mathrm{mg}$ and $200 \mathrm{mg}$, while at doses of $25 \mathrm{mg}$ and $50 \mathrm{mg}$, differences were not statistically significant [82].

In a multicenter, randomized, double-blind, parallel-group, placebo and active-controlled, Phase-2, proof-of-concept study (BLOSSOM trial), mirabegron $(150 \mathrm{mg})$ immediate release was associated with 
an increase of $5 \mathrm{bpm}$ in PR from the baseline versus placebo, while for mirabegron (100 $\mathrm{mg}$ ) IR and tolterodine ER, a significant difference vs placebo did not emerge [83].

A thorough study of QT/QTc on healthy volunteers [84] revealed that mirabegron has tendency to prolong QTc in female patients at supra-therapeutic doses (200 md daily). However, in subsequent phase-III clinical trials, mirabegron was well tolerated and, although no serious CV AEs were observed, slight, but statistically significant, increases in HR (1 bpm) were reported. On withdrawal of the drug, however, these AEs were reversed.

Overall, for what regards changes in HR elicited by mirabegron, these were more apparent in young healthy volunteers than among patients with OAB. This observation was attributed to the higher sensitivity of cardiac $\beta$-adrenoceptors (probably of the $\beta 1$-subtype) than in older individuals and in those with OAB.

On analyzing pooled results of three 12-week placebo-controlled phase III trials (SCORPIO, ARIES and CAPRICORN), Nitti et al. [85] found that mirabegron was associated with a small rise in HR versus placebo; this effect was dose-dependent and reversible on discontinuation of treatment. Specifically, the median increase from baseline elicited by mirabegron at $25 \mathrm{mg}, 50 \mathrm{mg}$ and $100 \mathrm{mg}$ was $1.3 \mathrm{bpm}, 1.4 \mathrm{bpm}, 2.3 \mathrm{bpm}$ for morning measurements, and $0.2 \mathrm{bpm}, 0.6 \mathrm{bpm}$, and $1.9 \mathrm{bpm}$ for afternoon measurements, respectively. Tachycardia events $(\mathrm{PR}>100 \mathrm{bpm})$ in mirabegron groups was $<$ $5 \%$ and, thus, comparable to those observed on placebo and tolterodine.

In the 12-month phase III safety study TAURUS, a small dose-dependent increase in HR from baseline $(<2 \mathrm{bpm})$ was recorded, which was comparable to that elicited by tolterodine [86]. Tachycardia events occurred in $1.0 \%$ and $2.3 \%$ in patients receiving mirabegron at $50 \mathrm{mg}$ and at $100 \mathrm{mg}$, respectively, and in $3.1 \%$ of patients receiving tolterodine.

In a randomized, double-blind, phase IIIb, non-inferiority study (BEYOND), mirabegron (50 mg) was associated with a mean increase in HR of $0.45 \mathrm{bpm}$ from the baseline [87].

In the non-Japanese Asians OAB study, mirabegron $(50 \mathrm{mg})$ elicited a slight increase in PR six hours after administration; this was smaller than in the tolterodine (4 mg) group (1.57 bpm vs $2.72 \mathrm{bpm}$ ) [88]. In another phase III study, conducted in Japan, a slight 2-bpm increase in PR was observed after 4week administration of mirabegron $(50 \mathrm{mg}$ ) versus placebo. Again, this effect was reversible and PR returned to its baseline value 2 weeks after the drug had been withdrawn [89].

\subsubsection{Blood pressure and hypertensive events}


The use of mirabegron is associated with a modest increase in blood pressure and hypertensive events (Table 3).

As emerged from a review by our group [42] that analyzed the pooled results of 12-week phase III trials and the results of a 12-month phase III trial, the mean difference in blood pressure at the end of treatment versus placebo was not clinically relevant, being below $1 \mathrm{mmHg}$ for the mirabegron doses tested. Hypertensive events in the pooled 12-week phase III trials declined as the dose of mirabegron increased, being $12 \%, 8.7 \%$ and $6.2 \%$ at doses of $25 \mathrm{mg}, 50 \mathrm{mg}$ and $100 \mathrm{mg}$, respectively. No statistically significant differences in hypertensive events emerged versus placebo and tolterodine at 4 $\operatorname{mg}[85]$.

Similar results were found on analyzing hypertensive events in the 12-month phase III trial, in which hypertensive events were recorded in $11 \%$ and $10 \%$ of patients in the mirabegron $50 \mathrm{mg}$ and $100 \mathrm{mg}$ groups, respectively. In addition, in this case, the differences in incidence versus tolterodine (11\%) were not statistically significant [86].

In the non-Japanese Asian OAB trial, the incidence of hypertension was $0.5 \%$ in the mirabegron $50 \mathrm{mg}$ group and $0.8 \%$ in the tolterodine ER $4 \mathrm{mg}$ group. The adjusted mean differences from placebo in SBP and DBP were also similar in the two groups [88].

In the QT/QTc study, mirabegron $(50 \mathrm{mg}$ ) was associated with mean increases of $4 \mathrm{mmHg}$ and 1.6 $\mathrm{mmHg}$ in SBP and DBP, respectively, versus placebo [85].

\subsubsection{QT prolongation}

It has been evaluated the association between mirabegron and QT prolongation (Table 4).

In the pooled 12-week population, the frequency of QTcF prolongation in mirabegron treatments groups was $<0.4 \%$, and it was comparable to that recorded in placebo and tolterodine groups. Moreover, a serious increase in QT ( $>500 \mathrm{msec}$ or increase of $60 \mathrm{~ms}$ from baseline) occurred only in 5 patients in mirabegron groups. This study did not reveal any difference between genders in terms of the frequency of QT prolongation [85]. In a 12-month trial, QT prolongation $>450 \mathrm{~ms}$ was seen in $4.9 \%$ and $3.9 \%$ at mirabegron doses of $50 \mathrm{mg}$ and $100 \mathrm{mg}$, respectively. These values were similar to that recorded in the tolterodine group (4.4\%), and QT prolongation was more frequent in females than males. Less than $0.4 \%$ of patients in both treatment groups suffered serious QT prolongation [86].

In a randomized placebo and moxifloxacin-controlled study conducted on 352 healthy individuals of both genders, mirabegron caused QT prolongation only at the supra-therapeutic dose of $200 \mathrm{mg}$, while mirabegron at $50 \mathrm{mg}$ and at $100 \mathrm{mg}$ did not elicit any major increase [84]. Furthermore, in the non- 
Japanese Asian OAB study, QTc prolongation occurred in $0.8 \%$ of patients treated with mirabegron at $50 \mathrm{mg}$; in none of these cases did QTc reach more than $480 \mathrm{~ms}$ [88].

In the studies analyzed, no cases of QT prolongation were associated with TdP.

\subsection{Combination therapy with a beta 3 agonist associated to an AM drug}

The concept of combining two drugs with different modes of action may be used in clinical practice to improve symptoms severity and health related quality of life in patients whose symptoms are not controlled with monotherapy. The advantage of this choice in terms of safety is the reduction of single drugs dosage and of their dose dependent AEs in consideration of synergistic drugs action.

A 12-week randomized placebo-controlled double-blind trial on 3494 patients with OAB demonstrated that combination of mirabegron $(25 \mathrm{mg})$ or mirabegron $(50 \mathrm{mg})$ and solifenacin $(5 \mathrm{mg})$ is correlated with clear improvements in urinary symptoms and treatment satisfaction compared with mirabegron and solifenacin as monotherapies. [90]

However, there is concern that combination of these drugs could also have a synergistic effect on heart receptors and could theoretically lead to exacerbation of CV side effects especially in old patients with CV comorbidities. The BESIDE study, a randomized double-blind study, was the first to investigate CV safety in $\mathrm{OAB}$ patients treated with a combination of mirabegron and solifenacin. It has shown that the frequency of CV AEs and changes in vital sign and ECG parameters were comparable between solifenacin alone (5 mg or $10 \mathrm{mg}$ ) and in combination with mirabegron thus demonstrating the lack of synergistic effect on heart tissue [91]. This was confirmed by another recent study [67] that investigated the efficacy and safety of combining mirabegron and solifencin. It demonstrated that the combination of these drugs at low doses can improve the tolerability profile in comparison with monotherapy, without compromising efficacy. This study also demonstrated no supra-additive effects on safety parameters. There was no dose-related difference in PR or BP between combination and single therapies with them. The fact that fewer AEs occurred on combination therapy than on solifenacin at $10 \mathrm{mg}$ as monotherapy, in addition to the absence of clinically significant additive AEs in terms of hypertension and PR, suggests that this twice therapy may offer benefits in patients intolerant to AM dose escalation requiring additional efficacy.

A recent phase III study has demonstrated that vibegron, a novel potent selective $\beta 3$ agonist, is clinically useful and safe for the treatment of patients with OAB. Furthermore vibegron, differently from mirabegron, did not show any induction and inhibitory effect on cytochrome (CYP) enzymes suggesting no risk of drug-drug interaction [92]. 
On the basis of this considerations, combinatory therapies of vibegron and AMs were tested in an interesting study of Di Salvo et al. [93]. In female Rhesus monkeys, the authors showed that by combining vibegron with AMs bladder relaxation improved. Moreover, it was found a better synergism when both M2 and M3-subtypes receptors were blocked. Indeed, this effect was greater with tolterodine than with darifenacin, a selective M3 receptor blocker. Although M2-subtype has only an indirect role in bladder relaxation, its inhibition leads to a greater effect of $\beta 3$ agonist, by increasing cyclic adenosine monophosphate (cAMP).

\section{Conclusions}

While AMs are the most commonly used drugs in the context of OAB, the $\beta 3$ agonist mirabegron constitutes a valid alternative. As OAB syndrome often affects elderly people, who may present $\mathrm{CV}$ comorbidities, and because the drugs prescribed may interact with receptors present both in the urinary and CV systems, the cardiologic consequences of the use of AMs and mirabegron have aroused great interest. The most common consequences of AMs use may be an increase in HR and QT interval. Increased HR may be associated with the use of fesoterodine, propiverine, tolderodine and trospium, while the other AMs do not present this AE. Various studies have reported that QT interval is not prolonged by AMs. Indeed, only three cases of QT prolongation and TdP have been reported with the use of solifenacin ( $5 \mathrm{mg}$ or $10 \mathrm{mg} / \mathrm{die}$ ) in women $>80$ years of age. QT prolongation must be taken into consideration when AMS are prescribed in females, particularly if they are elderly. Furthermore, interactions between AMs and drugs that compete for the same pathway, such as hepatic metabolism through cytochrome P450, may take place, thereby increasing QT. On the other hand, mirabegron, a selective $\beta-3$ agonist constitutes a good alternative for the treatment of OAB. This systematic review has shown that mirabegron presents similar efficacy and tolerability to AMs in phase II and III trials. Moreover, fewer AEs are reported, and these disappear on the discontinuation of the treatment. The most commonly reported AEs are either modest hypertension or a slight increase in HR. Unfortunately, long-term data are needed in order to confirm the CV safety and efficacy of mirabegron [42].

Furthermore, the combination of mirabegron and an AM drug such as solifenacin at low doses may be considered safe, without causing clinically significant additive effects in terms of hypertension and PR.

\section{Expert opinion}

AMs drugs are the most commonly prescribed drugs for $\mathrm{OAB}$, however long-term compliance is low due to perceived lack of efficacy and AEs. CV AEs are rare but noteworthy, are mainly reported in 
women who are more prone to develop QT prolongation, particularly if elderly. On the other hand, cardiac AEs has not to be necessarily attributed only to the drug itself but to the metabolic effects of the co-administered drug, which may increase the plasmatic levels of the agent. In conclusion, the CV safety profile of AMs seems to be good but an increase in HR and a prolongation of QT cannot be excluded as well as an increase in $\mathrm{CV}$ risk due to drug-drug interactions in old patients who present various comorbidities.

Conversely, mirabegron, a $\beta 3$-adrenoceptor agonist has shown similar efficacy and tolerability but reduced AEs. Hypertension was the most commonly reported AE associated with the administration of mirabegron but the increase of systolic blood pressure/diastolic blood pressure (SBP/SDP) was trivial and reversible upon treatment discontinuation. Furthermore, in all the studies there was no evidence of risk for the occurrence of severe CV AEs in all patients receiving mirabegron at all doses.

Furthermore, for AMs most data on patients with poorly controlled hypertension, arrhythmias or cardiac heart failure are currently missing because these patients are often excluded from clinical trials utilizing these drugs. For what regards mirabegron, more recent studies have provided a larger amount of data from real-world and all these studies confirm its efficacy and safety [79, 81].

Irrespective of the mechanism of action the clinical CV profile of mirabegron, when used at the recommended dose, gives no reason for alarm. Moreover, by combining mirabegron with a AM, the CV AEs may be further reduced.

In our opinion, despite the safe pharmacological profile of AMs and mirabegron, a clinical and ECG monitoring might be necessary throughout the administration period in selected patients such as those aged $>80$ years, those with coronary heart disease or congestive heart failure. In these patients, according to a recent consensus written by the American College of Cardiology, HR independently predicts outcomes so we have to be very cautious about using drugs causing tachycardia [94].

Unfortunately, a standardized clinical surveillance is difficult to recommend on the basis of the limited knowledge available from current literature

We hope that research will be oriented towards investigating the effects of long-term treatment with AMs or mirabegron on CV function in particular sub-populations of patients, such as the very elderly and those with CV disease. Furthermore, research should investigate the safety and efficacy of the newest and most selective AMs, such as imidafenacin and solifenacin, not only if taken singly but also, and especially, if associated with mirabegron.

According with recent studies, vibegron, a new potent $\beta 3$ agonist, is clinically useful and safe in the treatment of patients with $\mathrm{OAB}$, furthermore it does not interact with CYP enzymes. A direct head to 
head study comparing efficacy and safety of mirabegron and vibegron is required, furthermore we hope that future research will better investigate the safety and the efficacy of combination therapy with vibegron and AMs.

\section{Funding}

This paper has not been funded.

\section{Declaration of interest}

The authors have no relevant affiliations or financial involvement with any organization or entity with a financial interest in or financial conflict with the subject matter or materials discussed in the manuscript. This includes employment, consultancies, honoraria, stock ownership or options, expert testimony, grants or patents received or pending, or royalties. Peer reviewers on this manuscript have no relevant financial or other relationships to disclose 


\section{References}

\section{Papers of special note have been highlighted as: * of interest ** of considerable interest}

[1] Haylen BT, De Ridder D, Freeman R et al. An international Urogynecological association/International Continence society (ICS) joint report on the terminology for pelvic floor dysfunction. Int Urogynecol J 2010; 21: 5-26

[2] Irwin DE, Milsom I, Chancellor MB, Kopp Z, Guan Z. Dynamic progression of overactive bladder and urinary incontinence symptoms: a systematic review.Eur Urol. 2010 Oct;58(4):532-43.

[3] Kim TH, Lee ks. Persistence and compliance with medication management. In the treatment of overactive bladder. Invest Clin Urol 2016; 57: 84-96

[4] Cardozo L. Systematic review of overactive bladder therapy in females. Can Urol Assoc J. 2011 Oct; 5(5 Suppl 2): S139-S142.

[5] Wagg A, Compion G; Fahey A et al. Persistence with prescribed antinuscarinic therapy for overactive bladder: a UK experience. BJU Int 2012; 110: 1767-74

[6] Yeaw J, Benner JS, walt JG et al. Comparing adherence and persistence across 6 chronic medication classes. J Manag Care Pharm 2009; 15: 728-40

[7] Chapple CR, Cardozo L, Nitti VW, et al. Mirabegron in overactive bladder: a review of efficacy, safety and tolerability. Neurol urodynam 2014; 33(1): 17-30

[8]Asche CV, Kim J, Kulkarni AS et al. Presence of central nervous system, cardiovascular and overall co-morbidity burden in patients with overactive bladder disorderin a real-world setting. BJU Int 2012; 109: $572-80$

[9] Brodde OE, Michel MC. Adrenergic and muscarinic receptors in the human heart. Pharmacol Rev 1999; $51: 651-90$

[10] Abrams P, Andersson KE, Buccafusco JJ et al. Muscarinic receptors: their distribution and function in body sistems, and the implication s for treating overactive bladder. Br J Pharmacol 2006; 148(5): 565-78

[11] Andersson KE, Campeau L, Olshansky B et al. Cardiac effects of muscarinic receptor antagonists used for voiding disfunction. Br J Clin Pharmacol 2011; 72:186-96 
[12] Dhein S, Van Koppen CJ, Brodde OE. Muscarinic receptors in the mammalian heart. Pharmacol Res 2001; 44: 161-82

[13] Abramochkin DV, Suris MA, Borodinova AA et al. M3 cholinoreceptors: new mediator of acetylcholine action on myocardium. Neurochem J 2008; 2: 90-4

[14] Wang H, Shi H, Lu Y et al. Pilocarpine modulates the cellular electrical properties of mammalian hearts by activating a cardiac M3 receptor and a K+ current. Br J pharmacol 1999; 126: 1725-34

[15] Abramochkin DV, Tapilina SV, Sukhova GS et al. Functional M3 cholinoreceptors are present in pacemaker and working myocardium of murine heart. Eur J Physiol 2012; 463:m523-9

[16] Wang Z, Shi H, Wang H. Functional M3 muscarinic acetylcholine receptors in mammalian hearts. BR J Pharmacol 2004; 142: 395-408

[17] Gallo M.P; Alloatti G; Eva C et al. M1 muscarinic receptors increase calcium current and phosphoinositide turnover in guinea pig ventricular cardiocytes J Physiol 1993; 471: 41-60

[18] Lamping KG, Wess J, Cui Y, et al. Muscarinic (M) receptors in coronary circulation: gene-targeted mice define the role of M2 and M3 receptors in response to acetylcholine. Arterioscler Thromb Vasc Biol. 2004 Jul;24(7):1253-8.

[19] Fujimura T, Tamura K, Tsutsumi T et al.Expression and possible functional role of the beta3adrenoceptor in human and rat detrusor muscle. J Urol 1999; 161: 680-5

[20] Michel MC, Korstanje C. Beta 3-adrenoceptor agonists for overactive bladder syndrome: Role of translational pharmacology in re-positioning clinical drug development project. Pharmacol Ther 2016 mar; 159: 66-82

[21] Yamaguchi O. Beta3-adrenoceptors in human detrusor muscle. Urology 2002 May; 59 (5 Suppl I): $25-9$

[22] Brodde OE, Bruck H and Leineweber K. Cardiac adrenoceptors: physiological and pathophysiological relevance. J Pharmacol Sci 2006; 100(5): 323-37

[23] Baker AJ. Adrenergic signaling in heart failure: a balance of toxic and protective effects. Pflugers Arch. 2014 Jun;466(6):1139-5 
[24] Machuki J.O, Zhang HY, Harding SE et al. Molecular patways of oestrogen recetors and betaadrenergic receptors in cardiac cells. Recognition of their similarities interactions and therapeutic value. Acta Physiol (Oxf). 2018 Feb;222(2). doi: 10.1111/apha.12978.

[25] Skeberdis V, Gendviliene A, Zablockaite D et al. $\beta 3$-adrenergic receptor activation increases human atrial tissue contractility and stimulates the L-type calvium current. J Clin Invest 2008; 118 : $3219-27$

[26] Hutchinson DS, Bengtsson T, Evans BA, et al. Mouse beta 3a- and beta 3b-adrenoceptors expressed in Chinese hamster ovary cells display identical pharmacology but utilize distinct signalling pathways. Br J Pharmacol. 2002;135:1903-14

[27] Sterin-Borda L, Bernabeo G, Ganzinelli S et al Role of nitric oxide/cyclic GMP and cyclic AMP in beta3 adrenoceptor-chronotropic response. J Mol Cell Cardiol. 2006 Apr;40(4):580-8

[28] Rosa G.M, Bauckneht M, Scala C et al. Cardiovascular effects of antimuscarinic agents in overactive bladder. Expert Opinion on Drug Safety 2013 Nov; 12(6): 815-27 Interesting review about cardiovascular effets of antimuscarinic agents

[29] Cook S, Togni M, Schaub MC, et al. High heart rate: a cardiovascular risk factor? Eur Heart J 2006;27:2387-93

[30 Majercak I. The use of heart rate variability in cardiology. Bratisl Lek Listy 2002;103:368-77

[31] Palatini P., Julius S.Heart rate and the cardiovascular risk. J Hypertens 1997; 15: . 1-15

[32] Palatini P., Benetos A, Julius S. Impact of increased heart rate on clinical outcomes in hypertension. Drugs 2006; 66: 133-44

[33] Bentzon JF, Otsuka F, Virmani R ET AL. Mechanisms of plaque formation and rupture. Circ Res. 2014 Jun 6;114(12):1852-66.

[34] Witchel HJ. Drug-induced hERG block and long QT syndrome. Cardiovasc Ther 2011;29:251-9

[35] Schlotthauer K, Bers DM. Sarcoplasmic reticulum Ca2+ release causes myocyte depolarizationunderlying mechanism and threshold for triggered action potentials. Circ Res 2000;87:774-80 
[36] Makkar RR, Fromm BS, Steinman RT,et al. Female gender as a risk factor for torsades de pointes associated with cardiovascular drugs. JAMA 1993;270(21):2590-7

[37] Liu XK, Wang W, Ebert SN, et al. Female gender is a risk factor for torsades de pointes in an in vitro animal model. J Cardiovasc Pharmacol 1999;34(2):287-94

[38] Harris RZ, Benet LZ, Schwartz JB Gender effects in pharmacokinetics and pharmacodynamics. Drugs 1995 Aug; 50(2):222-39

[39] Mo W, Michel MC, Lee XW et al. The $\beta 3$-adrenoceptor agonist mirabegron increases human atrial force through $\beta 1$-adrenoceptors: an indirect mechanism? Br J Pharmacol. 2017 Aug;174(16):2706-2715

[40] Committee for Medicinal Products for Human Use (CHMP). Assessment report: Betmiga. European Medicines Agency Web site. http://www.ema.europa.eu/docs/en_GB/document library/EPAR_Public assessment report/human/00 2388/WC500137308.pdf

[41] Shen, Y. T., Zhang, H., \& Vatner, S. F. Peripheral vascular effects of beta-3 adrenergic receptor stimulation in conscious dogs. Journal of Experimental Therapeutics 1994 Jan; 268(1): 466-473.

[42] Rosa GM, Ferrero S, Nitti VW et al. Cardiovascular Safety of $\beta 2$-adrenoceptor agonists for the treatment of patients with overactive bladder syndrome. Eur Assoc Urol 2016; 69: 311-23. Very

\section{interesting review about Mirabegron}

[43] Iitsuka H, Tokuno T, Amada Y, et al. Pharmacokinetics of mirabegron, a beta3-adrenoceptor agonist for treatment of overactive bladder, in healthy Japanese male subjects: results from single and multiple-dose studies. Clin Drug Investig 2014;34:27-35.

[44] Korstanje C, Suzuki M, Yuno K,et al. Translational science approach for assessment of cardiovascular effects and proarrhythmogenic potential of the beta-3 adrenergic agonist mirabegron. $\mathrm{J}$ Pharmacol Toxicol Methods. 2017 Sep;87:74-81 
[45] Shen YT, Cervoni P, Claus T. et al, Differences in $\beta 3$-adrenergic receptor cardiovascular regulation in conscious primates, rats and dogs. J Pharmacol Exp Ther. 1996 Sep;278(3):1435-43.

[46] Shen YT., Zhang, H., Vatner SF. Peripheral vascular effects of beta-3 adrenergic receptor stimulation in conscious dogs. J Pharmacol Exp Ther. 1994 Jan;268(1):466-73.

[47] van Gelderen M, Stölzel M, Meijer J et al. An Exploratory Study in Healthy Male Subjects of the Mechanism of Mirabegron-Induced Cardiovascular Effects. J Clin Pharmacol. 2017 Dec;57(12):153444.

[48] Shimizu V, Antzelevich C. Differential effects of beta-adrenergic agonists and antagonists in LQT1, LQT2 and LQT3 models of the long QT syndrome. J Am Coll Cardiol. 2000 Mar 1;35(3):77886.

[49] Leone Roberti Maggiore U, Salvatore S, Alessandri A, et al. Pharmacokinetics and toxicity of antimuscarinic drugs for overactive bladder treatment in females. Expert Opin Drug Metab Toxicol 2012;8:1387-408. Interesting review about Pharmacokinetics and toxicity of antimuscarinic drugs [50] Nilvebrant L, Andersson KE, Gillberg PG, et al. Tolterodine a new bladder-selective antimuscarinic agent.Eur J Pharmacol 1997;327:195-207

[51] Olshansky B, Foote J, Arguinzoniz M,et al. The effects of darifenacin and tolterodine on heart rate (HR) in patients with overactive bladder (OAB) [abstract 124]. Annual Meeting of the 92. International Continence Society; Christchurch, New Zealand.2006. Available from:

https://www.icsoffice.org/publications/2006/pdf/0124.

[52 ] Hsiao SM, Chang TC, WU WY et al. Comparison of urodynamic effects, therapeutic efficacy and safety of solifenacin versus tolderodine for female overactive bladder syndrome. J Obstet J Res 2011; 37: $1084-91$

[53] Schiffers M, Sauermann P, Schurch B, et al. The effect of tolterodine 4 and $8 \mathrm{mg}$ on the heart rate variability in healthy subjects. World J Urol 2010;28:651-6

[54] Chapple C, Van Kerrebroeck PEV, Tubaro A, et al. Clinical efficacy, safety, and tolerability of once-daily fesoterodine in subjects with overactive bladder. Eur Urol 2007;52:1204-12 
[55] Nitti VW, Dmochowski R, Sand PK,et al. Efficacy, safety and tolerability of fesoterodine for overactive bladder syndrome. J Urol 2007;178:2488-94

[56] Abrams P, Cardozo L, Chapple C, et al. Comparison of the efficacy, safety and tolerability of propiverine and oxybutynin for the treatment of overactive bladder syndrome. Int J Urol 2006;13:692-8

[57] Sanctura XR_(trospium chloride extended release). US prescribing information. Allergan, Inc; Irvine (CA):2008

[58] Guay DR. Trospium chloride: an update on a quaternary anticholinergic for treatment of urge urinary incontinence. Ther Cli Risk Manag 2005; 1: 157-67

[59] Serra DB, Affrime MB, Bedigian MP et al. QT and QTc Interval With Standard and Supratherapeutic Doses of Darifenacin, a Muscarinic M3 Selective Receptor Antagonist for the Treatment of Overactive Bladder. J Clin Pharmacol. 2005 Sep;45(9):1038-47

[60] Olshansky B1, Ebinger U, Brum J et al. Differential Pharmacological Effects of Antimuscarinic Drugs on Heart Rate: A Randomized, Placebo-controlled, Double-blind, Crossover Study With Tolterodine and Darifenacin in Healthy Participants $\geq 50$ Years. J Cardiovasc Pharmacol Ther. 2008 Dec;13(4):241-51

[61] Chapple CR, Abrams P. Comparison of darifenacin and oxybutynin in patients with overactive bladder: assessment of ambulatory urodynamics and impact on salivary flow. Eur Urol. 2005 Jul;48(1):102-9.

[62] Homma Y, Yamaguchi O; Imidafenacin Study Group. A randomized, double-blind, placebo- and propiverine-controlled trial of the novel antimuscarinic agent imidafenacin in Japanese patients with overactive bladder. Int J Urol. 2009 May;16(5):499-506.

[63] Kang J, Chen XL, Wang H, et al. Cardiac ion channel effects of tolterodine. J Pharmacol Exp Ther. 2004 Mar;308(3):935-40.

[64] Christ T, Wettwer E Wuest E et all. Electrophysiological profile of propiverine - relationship to cardiac risk. Naunyn Schmiedebergs Arch Pharmacol. 2008 Feb;376(6):431-40 
[65] Bray JJH, Hancox JC. Solifenacin linked QT interval prolongation and torsades de pointes. Ther Adv Drug Saf. 2017 Jul;8(7):245-247

[66] Yamaguchi O, Kakizaki H, Homma Y, et al. Safety and efficacy of mirabegron as 'add-on' therapy in patients with overactive bladder treated with solifenacin: a post-marketing, open-label study in Japan (MILAI study). BJU Int 2015; 116(4): 612-22.

[67] Abrams P, Kelleher C, Staskin D, et al. Combination treatment with mirabegron and solifenacin in patients with overactive bladder: efficacy and safety results from a randomised, double-blind, doseranging, phase 2 study (Symphony). Eur Urol 2015; 67: 577-88.

[68] Asajima H, Sekiguchi Y, Matsushima S, et al. QT prolongation and torsade de pointes associated with solifenacin in an 81-year-old woman. Br J Clin Pharmacol 2008; 66: 896-97. Interesting clinical case of an old woman with QT prolongation and Tdp related to Solifenacin administration [69] Yoshida F, Okuso Y, Wada A, et al. Case report; a case of QT prolongation and torsade de pointes associated with solifenacin. Nihon Naika Gakkai Zasshi 2014; 103: 2804-06

[70]Ozmen N, Yiginer O, Un H, et al. Frequently occurring torsades de pointes attacks in an old patient on solifenacin therapy and management strategy. Anatol J Cardiol 2015; 15: 342-43

[71] Zeng H, Roman MI, Lis E, et al. Use of FDSS/ $\mu$ Cell imaging platform for preclinical cardiac electrophysiology safety screening of compounds in human induced pluripotent stem cell-derived cardiomyocytes. J Pharmacol Toxicol Methods 2016; 81: 217-22

[72] Thomas SH, Higham PD, Hartigan-Go K et al. Concentration dependent cardiotoxicity of terodiline in patients treated for urinary incontinence. Br Heart J. 1995 Jul;74(1):53-6.

[73] Stewart DA, Taylor J, Ghosh S et al. Terodiline causes polymorphic ventricular tachycardia due to reduced heart rate and prolongation of QT interval. Eur J Clin Pharmacol. 1992;42(6):577-80

[74] Larsson G, Hallen B, and Nilvebrant L. Tolterodine in the treatment of overactivebladder:analysis of the pooled phaseII efficacy and safety data.Urology 1999 may; 53(5):990-98

[75] Layton D, Pearce GL, and Shakir SA. Safety profile of tolterodine as used in general practice in England. Drug Safety. 2001; 24(9): 703-13.

[76] Donath F, Braeter M, Feustel C. The influence of propiverine hydrochloride on cardiac repolarization in healthy women and cardiac male patients. Int J Clin Pharmacol Ther 2011;49:353-65 
[77] Hussain RM, Hartigan-Go K, Thomas SH, et al. Effect of oxybutynin on the QT interval in elderly patients with urinary incontinence. Br J Clin Pharmacol 1996;41:73-5

[78] Kashyap M, Tyagi P.The pharmacokinetic evaluation of mirabegron as an overactive bladder therapy option. Expert Opin Drug Metab Toxicol. 2013 May;9(5):617-27

[79] Nozawa Y, Kato D, Tabuchi H et al. Safety and effectiveness of mirabegron in patients with overactive bladder in a real-world clinical setting: a Japanese post-marketing study. LUTS 2016; doi: 10.1111/luts 12148

[80] Balachandran A, Duckett J. The efficacy and tolerability of mirabegron in a non-trial clinical setting. Eur J Obst Ginecol and Reprod Biology. 2016 may; 200: 63-7

[81] Katoh T, Kuawamoto K, Kato D et al Real-world cardiovascular assessment of mirabegron treatment in patients with overactive bladder and concomitant cardiovascular disease: Results of a Japanese post-marketing study. Int J Urol 2016; 23: 1009-15

[82] Chapple CR, Dvorak V, Radziszewski P etal. AA phase II dose-ranging study of mirabegron in patients with overactive bladder. Int Urogynecol J (2013) 24:1447-1458

[83] Chapple CR, Amarenco G, Lopez MA et al. Proof-of-Concept Study: Mirabegron, a New Therapy for Overactive Bladder. Neurourol Urodyn. 2013 Nov;32(8):1116-22

[84] Malik M, van Gelderen EM, Lee JH et al. Proarrhythmic Safety of Repeat doses of Mirabegron in Healthy Subjects: A Randomized, double-Blind, Placebo-, and Active-controlled Thorough QT Study. Clin Pharmacol Ther. 2012 Dec;92(6):696-706.

[85] Nitti VW, Khullar V, van Kerrebroeck P et al. Mirabegron for the treatment of overactive bladder: a prespecified pooled efficacy analysis and pooled safety analysis of three randomised, double-blind, placebo-controlled, phase III studies. Int J Clin Pract. 2013 Jul;67(7):619-32

\section{Interesting paper about three phase III studies with Mirabegron}


[86] Chapple CR, Kaplan SA, Mitcheson D et al. Randomized double blind active controlled phase 3 study to assess 12-month safety and efficacy of Mirabegron a b3-adrenoceptor agonist, in overactive bladder. Eur Urol 2013;63:296-305

[87] Batista JE, Kolbl H, Herschorn Set al. The efficacy and safety of mirabegron compared with solifenacin in overactive bladder patients dissatisfied with previous antimuscarinic treatment due to lack of efficacy: results of a noninferiority, randomized, phase IIIb trial. Ther Adv Urol 2015, Vol. 7(4) $167-79$

[88] Kuo HC, Lee KS, Na Y, et al. Results of a randomized, double-blind, parallel-group, placebo- and active-controlled, multicenter study of mirabegron, a beta3-adrenoceptor agonist, in patients with overactive bladder in Asia. Neurourol Urodyn 2015;34:685-92.

[89] Yamaguchi O, Marui E, Kakizaki H, et al. Phase III, randomised, double-blind, placebo-controlled study of the beta3-adrenoceptor agonist mirabegron, $50 \mathrm{mg}$ once daily, in Japanese patients with overactive bladder. BJU Int 2014;113:951-60.

[90] Robinson D, Kelleher C, Staskin D.Patient-reported outcomes from SYNERGY, a randomized, double-blind, multicenter study evaluating combinations of mirabegron and solifenacin compared with monotherapy and placebo in OAB patients. Neurourol Urodyn. 2018 Jan;37(1):394-406.

[91] Drake MJ, MacDiarmid S, Chapple CR et al. Cardiovascular safety in refractory incontinent patients with overactive bladder receiving add-on mirabegron therapy to solifenacin (BESIDE). Int J Clin Pract. 2017 May;71(5)

[92] Yoshida M, Takeda M, Gotoh M et al. Vibegron, a Novel Potent and Selective $\beta 3$-Adrenoreceptor Agonist, for the Treatment of Patients with Overactive Bladder: A Randomized, Double-blind, Placebocontrolled Phase 3 Study. Eur Urol. 2018 Jan 20. pii: S0302-2838(17)31069-2 
[93] Di Salvo J, Nagabukuro H, Wickham LA et al. Pharmacological Characterization of a Novel Beta 3 Adrenergic Agonist, Vibegron: Evaluation of Antimuscarinic Receptor Selectivity for Combination Therapy for Overactive Bladder. J Pharmacol Exp Ther. 2017 Feb;360(2):346-55

[94] Yancy CW, Januzzi JL Jr., Allen LA et al. 2017 ACC Expert Consensus Decision Pathway for Optimization of Heart Failure Treatment: Answers to 10 Pivotal Issues About Heart Failure With Reduced Ejection Fraction: A Report of the American College of Cardiology Task Force on Expert Consensus Decision Pathways J Am Coll Cardiol. 2018 Jan 16;71(2):201-30 


\section{Tables}

Table 1. Summary of the cardiovascular adverse effects of AM drugs

\begin{tabular}{|c|c|c|c|c|}
\hline & HR & HRV & QTe & BP \\
\hline $\begin{array}{l}\text { Darifenacine } \\
\text { Hydrobromide }\end{array}$ & $\begin{array}{l}\text { No significant } \\
\text { change is } \\
\text { reported }[60,61]\end{array}$ & $\begin{array}{l}\text { No significant } \\
\text { change is } \\
\text { reported }[60,61]\end{array}$ & $\begin{array}{l}\text { No significant } \\
\text { change is } \\
\text { reported neither } \\
\text { in poor } \\
\text { metabolizers[59] }\end{array}$ & $\mathrm{NA}$ \\
\hline $\begin{array}{l}\text { Fesoterod } \\
\text { fumarate }\end{array}$ & $\begin{array}{l}\text { dose related } \\
\text { increase }(\leq 4 \\
\text { bpm) }[54,55]\end{array}$ & $\begin{array}{l}\text { No significant } \\
\text { change is } \\
\text { reported }[54,55]\end{array}$ & $\begin{array}{l}\text { No significant } \\
\text { change is } \\
\text { reported }[54,55]\end{array}$ & $\begin{array}{l}\text { No significant } \\
\text { change is } \\
\text { reported[54,55] }\end{array}$ \\
\hline $\begin{array}{l}\text { Tolterodine } \\
\text { taltrate }\end{array}$ & $\begin{array}{l}\text { increase of } 3 \\
\text { bpm [52] } \\
\text { increase of } 10 \\
\text { bpm with } 8 \mathrm{mg} \\
\text { dosage[53] no }\end{array}$ & $\begin{array}{l}\text { Relevant effect at } \\
\text { supraterapeutic } \\
\text { dose, slight effect } \\
\text { with } 4 \mathrm{mg} \text { in } \\
\text { healthy subjects, }\end{array}$ & $\begin{array}{l}\text { No significant } \\
\text { change is } \\
\text { reported } \\
{[83,85,86]}\end{array}$ & $\begin{array}{l}\text { No significant } \\
\text { change is } \\
\text { reported } \\
{[83,85,86]}\end{array}$ \\
\hline
\end{tabular}




\begin{tabular}{|c|c|c|c|c|}
\hline & $\begin{array}{l}\text { significant } \\
\text { increase with ER } \\
\text { preparation } \\
{[51,83,86]}\end{array}$ & $\begin{array}{l}\text { relevant in } \\
\text { patients with } \\
\text { OAB [51-53] }\end{array}$ & & \\
\hline $\begin{array}{l}\text { Trospium } \\
\text { chloride }\end{array}$ & $\begin{array}{l}\text { Increase of } 14 \\
\text { bpm for i.v } \\
\text { preparation, not } \\
\text { relevant for oral } \\
\text { use [58] }\end{array}$ & NA & $\begin{array}{l}\text { No significant } \\
\text { change is } \\
\text { reported [58] }\end{array}$ & NA \\
\hline $\begin{array}{l}\text { Oxybutynin } \\
\text { chloride }\end{array}$ & $\begin{array}{l}\text { No significant } \\
\text { change is } \\
\text { reported }[56,61]\end{array}$ & $\begin{array}{l}\text { No significant } \\
\text { change is } \\
\text { reported }[56,61]\end{array}$ & $\begin{array}{l}\text { No significant } \\
\text { change is } \\
\text { reported [77] }\end{array}$ & $\mathrm{NA}$ \\
\hline $\begin{array}{l}\text { Propiverine } \\
\text { hydrochloride }\end{array}$ & $\begin{array}{l}\text { increase of } 4.4 \\
\text { bpm[62] }\end{array}$ & Reduction [56] & $\begin{array}{l}\text { QTprolongation } \\
\text { but no } \\
\text { increase }>500 \\
\text { msec; no increase } \\
\text { in healthy } \\
\text { women [76] }\end{array}$ & NA \\
\hline $\begin{array}{l}\text { Solifenacin } \\
\text { succinate }\end{array}$ & No effect $[56,87]$ & NA & $\begin{array}{l}\text { Three cases of } \\
\text { TdP }[68,69,70] \\
\text { small increase of } \\
\text { QTc }[66,67]\end{array}$ & No effect $[56,87]$ \\
\hline Imidafenacin & $\begin{array}{l}\text { Not significant } \\
{[62]}\end{array}$ & NA & $\begin{array}{l}\text { Not significant } \\
{[62]}\end{array}$ & NA \\
\hline
\end{tabular}

$\mathrm{HR}=$ heart rate; $\mathrm{HRV}=$ heart rate variability; $\mathrm{BP}=\mathrm{Blood}$ pressure; $\mathrm{NA}=$ no data available; $\mathrm{bpm}=$ beats per minute 


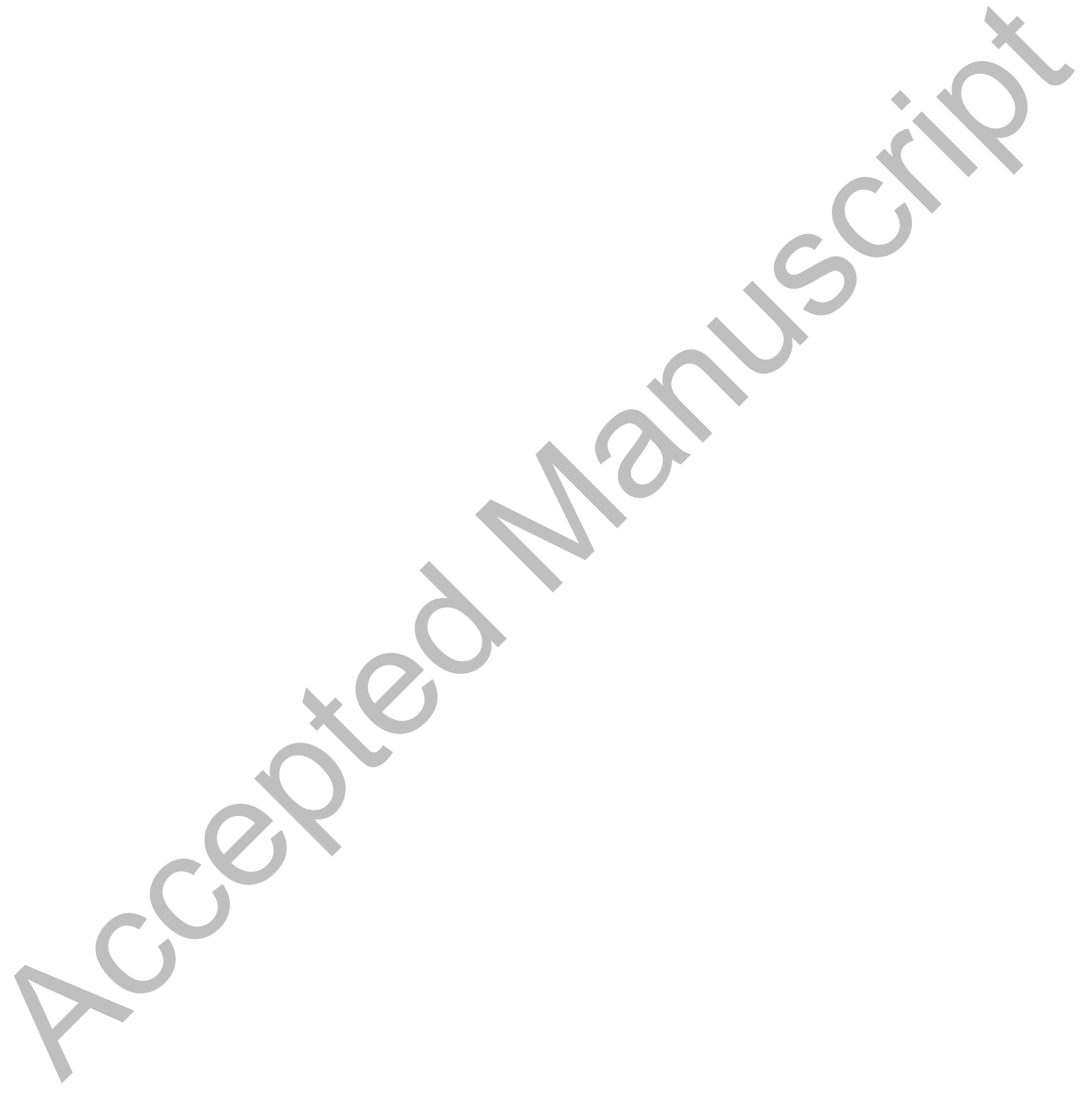


Table 2. Change from baseline in Pulse rate and tachycardia events

\begin{tabular}{|c|c|c|c|c|}
\hline & $\begin{array}{l}\text { PR AM } \\
\text { (bpm) } \\
\text { mean } \\
\text { change } \\
\text { from } \\
\text { baseline } \\
t\end{array}$ & $\begin{array}{l}\text { PR PM (bpm) mean } \\
\text { change from baseline } 1\end{array}$ & $\begin{array}{l}\text { PR (bpm) mean change } \\
\text { from baseline } \neq\end{array}$ & $\begin{array}{l}\text { Tachycardia incidence } \\
\text { N (\%) \# }\end{array}$ \\
\hline \multicolumn{5}{|l|}{ Pooled 12 week phase III } \\
\hline Placebo $(n=1380)$ & 0.4 & -0.4 & NA & $43(3.1)$ \\
\hline Mirabegron $25 \mathrm{mg}(\mathrm{n}=432)$ & 1.3 & 0.2 & & $21(4.9)$ \\
\hline Mirabegron 50 mg $(n=1375)$ & 1.4 & 0.6 & & $52(3.8)$ \\
\hline Mirabegron 100 mg $(n=929)$ & 2.3 & & & $43(4.6)$ \\
\hline \multicolumn{5}{|l|}{ BEYOND } \\
\hline Mirabegron $50 \mathrm{mg}(\mathrm{n}=936)$ & $\mathrm{NA}$ & NA & 0.5 & $17(1.8)$ \\
\hline \multicolumn{5}{|l|}{ TAURUS } \\
\hline $\begin{array}{l}\text { Mirabegron } 50 \mathrm{mg}(\mathrm{n}=812) \\
\text { Mirabegron } 100 \mathrm{mg}(\mathrm{n}=820)\end{array}$ & $\begin{array}{l}0.9 \\
1.6\end{array}$ & $\begin{array}{l}0.4 \\
1.3\end{array}$ & NA & NA \\
\hline BLOSSOM & & & & \\
\hline
\end{tabular}




\begin{tabular}{|c|c|c|c|c|}
\hline $\begin{array}{l}\text { Placebo } \\
\text { Mirabegron } 100 \text { mg BID }(n=65) \\
\text { Mirabegron } 150 \text { MG BID }(n=65)\end{array}$ & NA & NA & $\begin{array}{l}5 \\
-0.7\end{array}$ & NA \\
\hline \multicolumn{5}{|l|}{ DRAGON } \\
\hline Placebo $(n=166)$ & 0.51 & -0.04 & NA & NA \\
\hline Mirabegron $25 \mathrm{mg}(\mathrm{n}=167)$ & 0.3 & 0.4 & & \\
\hline Mirabegron $50 \mathrm{mg}(\mathrm{n}=167)$ & 1.6 & 1.1 & & \\
\hline Mirabegron $100 \mathrm{mg}(\mathrm{n}=168)$ & 2.2 & 2.7 & & \\
\hline Mirabegron $200 \mathrm{mg}(\mathrm{n}=168)$ & 4.7 & 4.7 & & \\
\hline
\end{tabular}

$\mathrm{PR}=\mathrm{Pulse}$ rate; 1 measured by patients and reported on diary; $\neq$ measured at visit; \# based on TEAE or asymptomatic PR measure by patients $>100 \mathrm{bpm} ; \mathrm{NA}=$ no data available; $\mathrm{BID}=$ twice day

Table 3. Change from baseline in blood pressure and hypertensive events

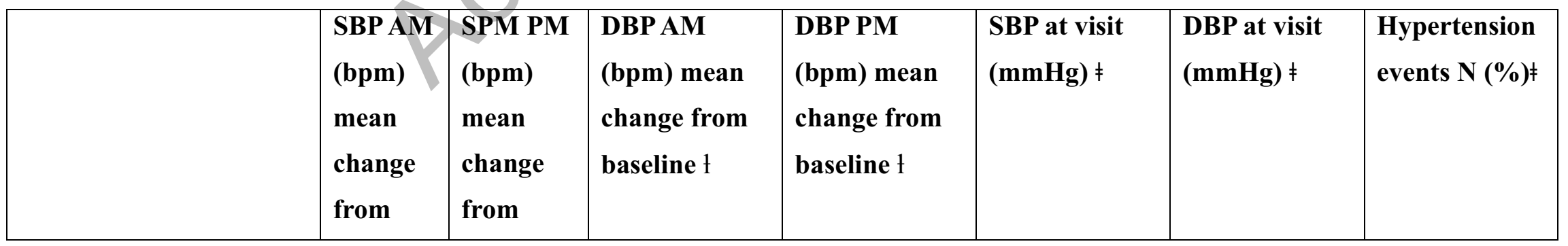




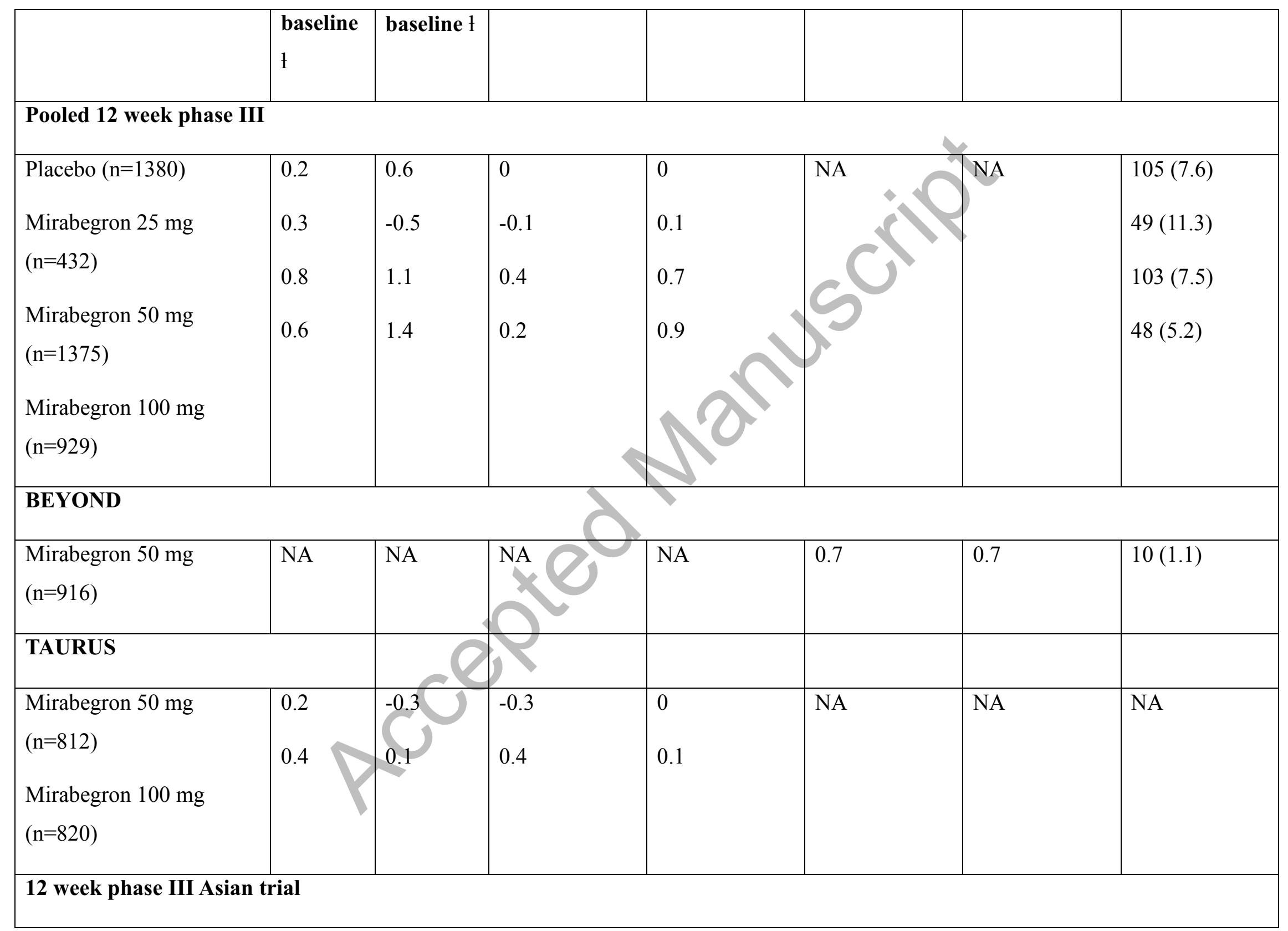




\begin{tabular}{|l|l|l|l|l|l|l|l|}
\hline $\begin{array}{l}\text { Mirabegron 50 mg } \\
(\mathrm{n}=366)\end{array}$ & $-1.38 \#$ & NA & $1.82 \#$ & NA & NA & NA & $2(0.5)$ \\
\hline
\end{tabular}

$\mathrm{SBP}=$ systolic blood pressure; $\mathrm{DBP}=$ diastolic blood pressure; 1 measured by patients and reported on diary; $\ddagger$ measured at visit; \# mean difference from placebo; $\mathrm{NA}=$ no data available

Table 4. Number of patients with QTcF changes from baseline

\begin{tabular}{|c|c|c|c|c|c|}
\hline & $\begin{array}{l}\text { QTcF }>450 \\
\text { ms N (\%) }\end{array}$ & $\begin{array}{l}\text { QTcF }>480 \\
\text { ms N (\%) }\end{array}$ & $\begin{array}{l}\text { QTcF }>500 \mathrm{~ms} \mathrm{~N} \\
(\%)\end{array}$ & QTcF $>30$ ms N (\%) & QTcF $>60 \mathrm{~ms} \mathrm{~N}(\%)$ \\
\hline \multicolumn{6}{|l|}{ TAURUS } \\
\hline Mirabegron $50 \mathrm{mg}(\mathrm{n}=812)$ & $36(4.9)$ & 5 & $2(0.3)$ & $76(10)$ & $3(0.4)$ \\
\hline Mirabegron $100 \mathrm{mg}(\mathrm{n}=820)$ & $29(3.9)$ & & $1(0.1)$ & $67(9.0)$ & $3(0.4)$ \\
\hline \multicolumn{6}{|c|}{ Pooled 12 week phase III studies } \\
\hline Placebo $(n=1380)$ & $44(3.5)$ & $3(0.2)$ & $1(0.1)$ & $44(3.6)$ & $2(0.2)$ \\
\hline Mirabegron $25 \mathrm{mg}(\mathrm{n}=432)$ & $14(3.4)$ & 0 & 0 & $9(2.2)$ & $1(0.2)$ \\
\hline Mirabegron $50 \mathrm{mg}(\mathrm{n}=1375)$ & $32(2.6)$ & $3(0.2)$ & 0 & $54(4.3)$ & $1(0.1)$ \\
\hline Mirabegron $100 \mathrm{mg}(\mathrm{n}=929)$ & $27(3.2)$ & $5(0.6)$ & $1(0.1)$ & $24(2.9)$ & $2(0.2)$ \\
\hline
\end{tabular}


$\mathrm{QTcF}=\mathrm{QTc}$ interval measured using Fridericia correction method

Figure 1

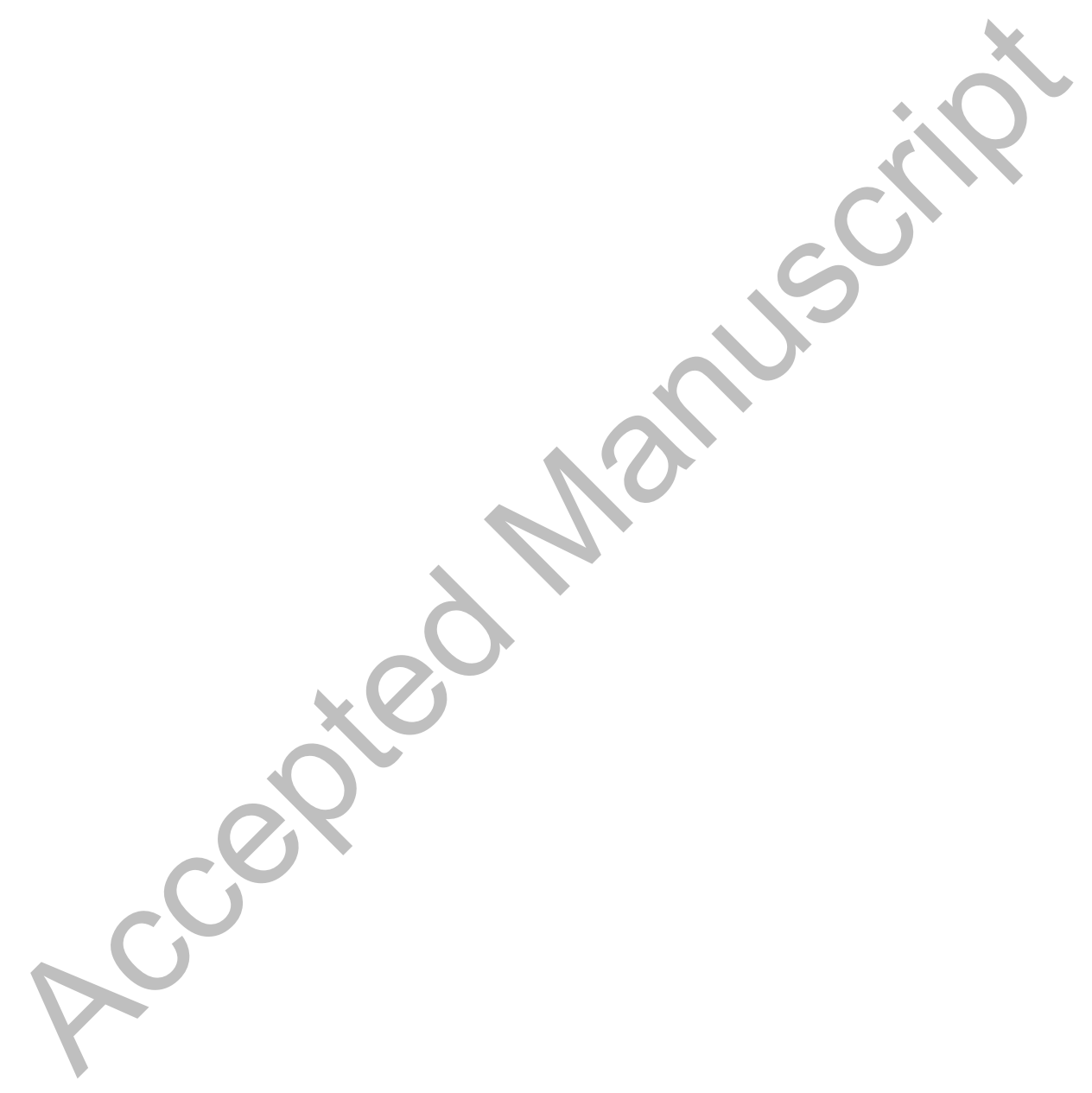




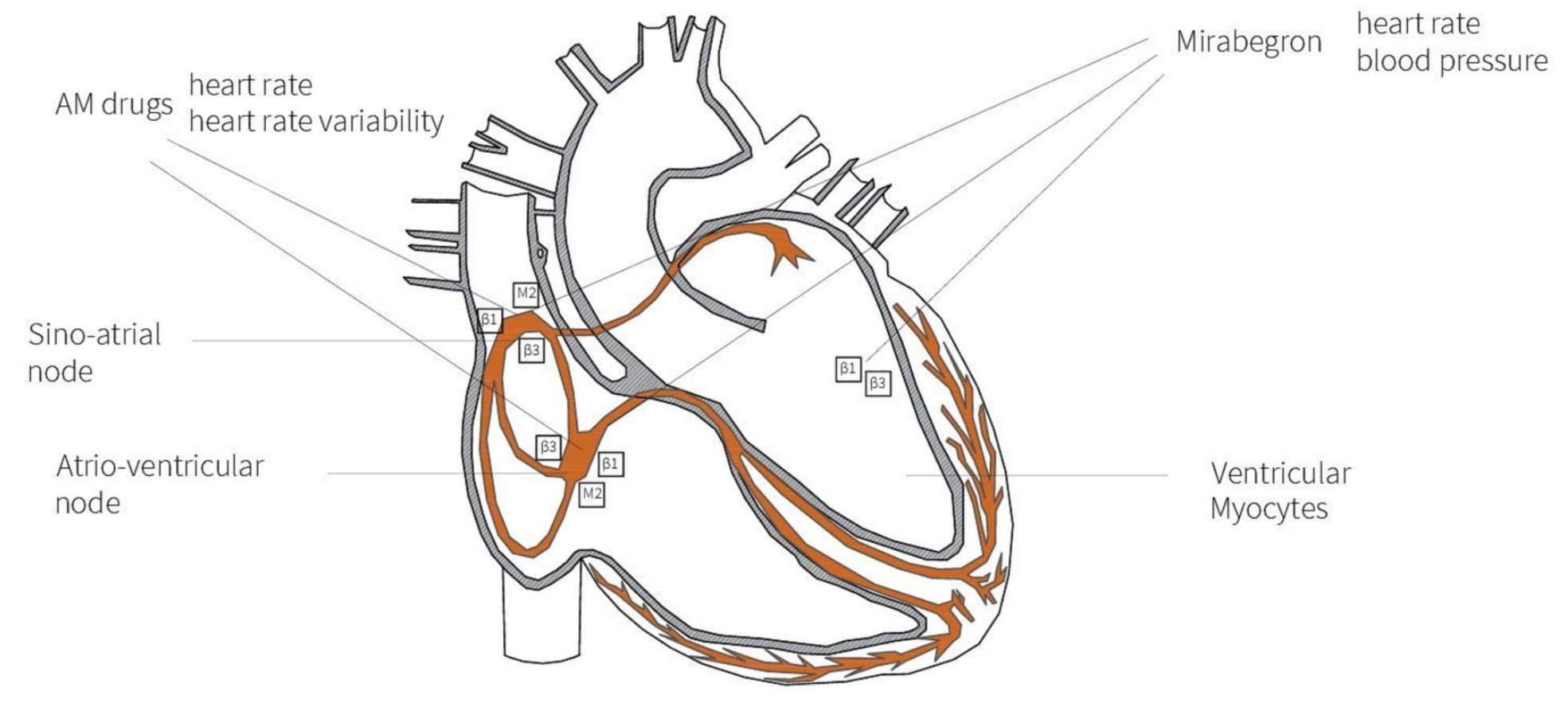

